Journal of Economics and Behavioral Studies

Vol. 7, No. 3, pp. 119-126, June 2015 (ISSN: 2220-6140)

\title{
The Effect of Organizational Communication towards Employees' Performance of the Badan Pendidikan Dan Pelatihan in Makassar City
}

\author{
Hikmah \\ Hasanuddin University, Makassar, Indonesia \\ hikmahnurdin77@gmail.com
}

\begin{abstract}
Effective communication in organization is important to regulate the role of organization, coordination, controlling and evaluation from leader to staff and staff to leader, and miscommunication in information can lead to wrong-decision making and ineffective. This research is aimed to explain the importance of communication and its effect in organization by using the methodology of a simple linear regression. Two-way communication model (vertical and horizontal) proved to be effective within this organization based on the findings in this study. This model helped in reaching effective organization like well-established organization atmosphere, excellent employee performance and job finishing punctuality. The importance of communication in the organization is undisputable consequence. Organizational communication allows the company to obtain a valuable result which is unachievable by any standalone individuals. It is then understood that without cooperation from individuals in the organization, the organizational goal is not achievable. The weakness of this study appeared in the government sector due to the small scope held only in Badan Pendidikan dan Pelatihan office.
\end{abstract}

Keywords: Organizational communication and employees' performance

\section{Introduction}

Background: Achieving goals in an organization or institution might be made possible by forcing massive effort acted by those involved in the organization. An institution, both government and private, must set an organization driven by a group of people who play an active role to achieve the objectives of the organization or institution. Achieving the objectives of organization or institution is strongly influenced by the performance of an individual. In other words, if the employees perform well, it might contribute a positive performance to the organization. When employees are able to communicate to each other, the organization can run in accordance with the functions. In one organization, the communication process between members of the organization is applied in various systems. Hence, the communication within an organization has two important functions, allowing those involved in the Organization to share necessary information and defining member of organizations from those who are not. Employees' performance is an economical source and power-driven requiring technical and organizational skills to arrive in excellent results, meaning that the results obtained are processed through various balanced input. The energy deployed effectively without wasting any second will be more efficient in the achievement of the objectives.

Therefore, the performance of employees becomes a standard measurement of success in performing the given task for civil servants. And when it began to decline, finding a contributing factor should be attempted. One of the major causes is a wrong decision policy taken by the superior. Though these decisions have been discussed during the communication process among the members and the leader, it appears to be ineffective to cope with the existing problems that unfortunately affect the performance of its employees. Thus, finding solution is strongly advisable. Satisfactory results of the listed problems at Badan Pendidikan dan Pelatihan in Makassar city have not been identified. The development of Employee's performance at Badan Pendidikan dan Pelatihan in Makassar city can be easily recognized from several aspects, for example an achievement in the employee work efficiency including adequate working hours and punctuality as well as budget efficiency. This development of the performance was also supported by adequate working condition seen from the output and standardization of work that has been optimally applied without any delays to the main task. The other thing is the uniformity in educational background of every employee affects the completion of tasks on time. Based on the explanation above, the author is interested in reviewing this issue becomes a title: "The 
Effect of Organizational Communication towards Employees' Performance of the Badan Pendidikan dan Pelatihan In Makassar City

Identification of the Problems: From the background of the issue above, the author identifies the problem as follows:

- What is the description of the organizational communication at Badan Pendidikan dan Pelatihan in Makassar city?

- How is the description of the performance level of employees at Badan Pendidikan dan Pelatihan in Makassar city?

- How is the effect of Organizational communication towards employees' performance at Badan Pendidikan dan Pelatihan in Makassar city?

Objective of Writing: The goals of this research are:

- To know the description of the Organizational communication at Badan Pendidikan dan Pelatihan in Makassar City

- To know the description of the performance level of employees at Badan Pendidikan dan Pelatihan in Makassar City

- To know the effect of Organizational communication towards employees' performance at Badan Pendidikan dan Pelatihan in Makassar city?

\section{Theoretical Framework}

The definition of Organizational communication: Communication is a process of sharing information between individuals within a common system. Not only with the symbols and signals but also with behaviors or action. Various definitions of communication are asserted to limit the meaning of communication. Opinions from the experts concerning the communication are presented as follows:

- According to Redding and Sanborn in Arni (2008:65), organizational communication is the sending and receiving of information in complex organizations. Included in the field of international communication, human relations, relationship management, communication union of superiors to subordinates, communication from subordinates to superiors.

- According to Zelko and Danse in Arni (2008:66) Organizational communication is the interdependence system that includes internal and external communication. Internal communication is communication within the organizational itself. Such as communication from subordinates to superiors, communications from superiors to subordinates, as well as the communication to the same level as their fellow employees. While the external communication is communication that is done to the environment outside from the organization, such as the communication in the sales of the production's result, advertising creation and relations with the general public.

The purpose of Organizational Communication: A communication process is a series of activities to get understanding of one another. A successful communication happens when a series of sources (communicator) to the receiver (recipient) occurs.

The definition of Performance: Performance is a level of achievement of specific task or job implementation. The performance of organization is the accumulation of all organization units' performance (summation of everyone's performance). The performance is a result of the quality and quantity of work achieved by one employee in the performance of his duties in accordance with the responsibilities given to him. The research team of Development of Accountability System for Performance Government (2000: 8) gives the definition of the performance, i.e. "performance is the degree of effectiveness and efficiency and ability in the achievement of the objectives by the management and the divisions that exist within an organization". According to the Indonesian dictionary (2002:570) "Performance is defined as something that is achieved, achievement and demonstrated ability to work."

According to Prabu (2002: 67) states that Performance is the result of the quality and quantity of work achieved by an employee in carrying out their duties in accordance with the responsibilities assigned to him. 
Sulistiyani (2003:223) asserts that a person's performance is a combination of ability, effort and opportunity that can be judged from his work". Whereas Hasibuan (2007:34) suggests that the performance is a result of work which is accomplished by person in carrying out the duties charged to him based on the skills, experience and time commitment. Irham Fahmi (2010:2) says that performance is the result obtained by an organization that is profit oriented and nonprofit oriented which produced during the period time. Meanwhile, according to Soeprihanto (2000:7) says that the performance of an employee is essentially the work of a person during a certain period in comparison with the various possibilities, such as standards, targets/goals or criteria have been determined in advance and agreed upon together. Certainly in terms of assessment, still consider the variety of situations and conditions that affect the achievement of the work.

\section{Methodology}

Time and Place of the Research: The location of this research is in Badan Pendidikan dan Pelatihan in Makassar City which is located on Jl.Sultan Alauddin with 3 months study: February until May 2013.

Method of Data Collection: In this research, data collection was carried out through:

- Questionnaire, Data collecting dealing with the performance of employees by asking them to complete covered questions. The answer in the question form has been carefully selected and prepared by the researcher, so respondents simply choose an alternative answer to suit the circumstances. The multiple choice form was set for this questionnaire and the details of the question are provided with several alternative answers, A, B, C, and D.

- Interview, Data collecting by direct - questioning to the Leader and staff who have deep understanding about the data needed.

- Observation, Data collecting techniques done through direct observation of the situation, about the activities that relate to the activity of employees.

\section{Types and Source of the Data}

Types of the Data: This research was qualitative and quantitative data

Source of the Data: The source of the data in this research was the subject of the acquired data (Arikunto, 2003:114). In order to support the writing activities to be done properly and as expected, required data should be objective and relevant.

- Primary Data, i.e. data obtained directly from the source, observed and recorded for the first time (Marzuki, 2002: 55). Primary is the raw data and has not yet been processed from questionnaires, interviews and observation.

- Secondary Data, i.e. data from the documents, collected both from the targeted institution and other relevance documents to this research.

Method for Analyzing Data: In writing of this research, the researcher used the descriptive and qualitative method. Those methods are the way to collect the data which contains the descriptions, exposure of an object according to the required criteria.

Then this method can be used with simple linear regression using the formula:

$\mathrm{Y}=\mathrm{a}+\mathrm{bx}$

Where is: $\quad Y=$ Performance

$\mathrm{a}=$ Constant (Fixed Value)

$\mathrm{x}=$ Communicational Organization

\section{Population and Sample}

Population: Population is the total number of objects that are examined. The population of this research is all the 44 employees in Badan Pendidikan dan Pelatihan in Makassar city.

Sample: Sample is half of the population becoming object of the research. According to Arikunto (2003: 87), when the population is less than 100, the total number should be the sample. Thus, all 44 employees in this research are becoming the sample. 
Operational Definition of Variables: The operational variables are defined:

Organizational Communication is a process of exchanging information between individuals through a common system (customary) either with a symbols, signals and behaviors or actions. The indicators as follows:

- Effective downward communication is the communication which flows from higher authority hierarchy to the lower hierarchy and through a range of channels of command.

- Effective Upward Communication is communication that goes from subordinates to superiors or from lower organization to the higher organization.

- Effective Horizontal Communication is the Communication that occurs between members of the organization that have the same level in an organization.

Performance is the result of the quality and quantity of work achieved by an employee in carrying out their duties in accordance with the responsibilities assigned to him. The indicators are as follows:

- The quality of work based on established standards. Quality of work is measured by the indicators of accuracy, thoroughness, skill and success of the work.

- The quantity of work is the balance of working output and working hours. The major concern does not focus on the regular output but merely the time needed.

- Punctuality; punctuality in completing the task, in presence, in recess, and in time-to-go-home.

\section{Findings and Discussion}

\section{Presentation and Data Analysis}

Characteristics of Respondent: Respondent is a group of people who are being the sample during the process of collecting research data. The respondents in this research were 44 employees at Agency's Office of Badan Penelitian dan Pelatihan in Makassar City. The composition of the respondents is based on sample data and sex with 24 male or $54.54 \%$ and 20 female or $45.46 \%$ as shown in table 2 below:

\section{Table 1: The composition of the respondent based on the sex}

\begin{tabular}{lcc}
\hline Sex & Total & Percentage (\%) \\
\hline Male & 24 & $54.54 \%$ \\
Female & 20 & $45.46 \%$ \\
Total & 44 & 100 \\
\hline
\end{tabular}

Source: Primary data processed by 2013

Based on the data from the institution, if categorized by level of education, the percentage of senior high school consist of $27.72 \%$, undergraduate $43.18 \%$, postgraduate $27.27 \%$, and $\mathrm{PhD} 2.27 \%$, as shown in table 2 below:

Table 2: The composition of the respondent based on the education level

\begin{tabular}{lcc}
\hline Education & Total & Percentage \\
\hline Senior High School & 12 & 27.27 \\
S1 & 19 & 43.18 \\
S2 & 12 & 27.27 \\
S3 & 1 & 2.27 \\
Total & 44 & 100
\end{tabular}

Source : Primary data processed by 2013

Description of the research variables: Description of Organizational communication and Performance Variables Organizational communication is a process of exchanging information between individual through a common system (customary) either with a symbol of symbols, signals and behaviors or actions. 


Table 3: The overview of organizational communication in Badan Pendidikan dan
Makassar City
\begin{tabular}{|lllll}
\hline No & Interval & A Choice Answer & Frequency & \% \\
\hline 1 & $4.00-3.54$ & Often & 22 & 50.00 \\
2 & $3.46-2.54$ & Always & 17 & 38.00 \\
3 & $2.46-1.54$ & Sometimes & 5 & 11.00 \\
4 & $1.50-1.00$ & Never & - & \\
& & Total & 44 & 100 \\
\hline
\end{tabular}

Data source : the result of data processing 2013

From the table above, the answer of the respondent to the organizational communication are 22 or $50 \%$ of the respondents stated often, 17 respondents or $38 \%$ stated always, 5 respondents or $11 \%$ stated sometimes.

Table 4: The description of the performance's variables

\begin{tabular}{lllll}
\hline No & Interval & A Choice Answer & Frequency & \% \\
\hline 1 & $4.00-3.54$ & Often & 8 & 18 \\
2 & $3.46-2.54$ & Always & 23 & 52 \\
3 & $2.46-1.54$ & Sometimes & 13 & 29 \\
4 & $1.50-1.00$ & Never & - & \\
& & Total & 44 & 100 \\
\hline
\end{tabular}

Based on the table 4 above, the employee's performance in the Office of Badan Pendidikan dan Pelatihan in Makassar City is in middle category with 23 respondents or $52 \%$. This can theoretically seen from the time spent in completing the task. This indicates that the employee's performance of Badan Pendidikan dan Pelatihan in Makassar City must be improved.

$$
\begin{array}{ll}
\mathrm{n}=44 & \sum \mathrm{x}^{2}=74562 \\
\sum \mathrm{x}=1782 & \sum \mathrm{y}^{2}=75974 \\
\sum \mathrm{y}=1806 & \sum \mathrm{xy}=74864
\end{array}
$$

Based on the data in the calculation table, to find out the degree of the relationship between $\mathrm{X}$ and $\mathrm{Y}$, coefficient of correlation with equation formula is used :

$$
\begin{gathered}
r=\frac{n\left(\sum x y\right)-(x y)}{\sqrt{n\left(\sum x^{2}\right)}-\left(\sum x\right)-n\left(\sum y^{2}\right)-\left(\sum y\right)^{2}} \\
=\frac{44(74864)-(1782)(1806)}{\sqrt{44(74562)-(1782)^{2}-44(75974)-(1806)^{2}}} \\
=\frac{3,294,016-3,218,292}{\sqrt{(3,280,728-3,175,524)-(3,342,856-3,261,636)}} \\
=\frac{75,724}{\sqrt{105,204-81,220}} \\
=\frac{75,724}{\sqrt{23,984}} \\
=\frac{75,724}{154.86} \\
=0.49
\end{gathered}
$$

The calculation above shows that the coefficient of correlation between organizational communication (X) and Employee's performance $(\mathrm{Y})$ is $r=0.49$, it means that there is a positive relationship between variable $\mathrm{X}$ and variable Y. Table 5 below interprets the correlation of coefficients: 
Table 5: The coefficient of correlation and its function

\begin{tabular}{ll}
\hline Interval of coefficients & The level of influence \\
\hline $0.00-0.199$ & Very Low \\
$0.20-0.399$ & Low \\
$0.40-0.559$ & Medium \\
$0.60-0.799$ & Strong \\
$0.80-1.000$ & Very Strong \\
\hline
\end{tabular}

Source: Coefficient of correlation Table

Then to analyze how much the influence of organizational communication towards the employee, the coefficient of determination (kd) with the formula is used:

$$
\begin{aligned}
\mathrm{kd} & =r \times 100 \% \\
& =0.49^{2} \times 100 \% \\
& =24 \%
\end{aligned}
$$

The result of calculation shows that every changes in the performance of employees was affected by the organizational communication, $\mathrm{kd}=24 \%$, the residue is influenced by others are influenced by family, organization, and social environment. Based on the table and the previous calculation, it can be interpreted that the correlation between $\mathrm{X}$ and $\mathrm{Y}$ belong to the medium relationship $0.49 \%$. To indicate whether the correlation coefficient ( $\mathrm{r}$ ) has a close relationship (significant) or not, hypothesis test needs to be done. Hypothesis testing to find out how strong the relationship or influence independent variable $(\mathrm{X})$ and the dependent variable $(\mathrm{Y})$ is, t-test is used with the formula:

$$
\begin{aligned}
\mathrm{t} & =\frac{r^{2 \sqrt{n-2}}}{\sqrt{1-r^{2}}} \\
= & \frac{0.49^{2 \sqrt{44-2}}}{\sqrt{1-0.49^{2}}} \\
= & \frac{(0.24)(6.48)}{\sqrt{1-0.24}} \\
= & \frac{1.55}{0.87} \\
= & 1.78
\end{aligned}
$$

If $t$ count is bigger than $t$ table on certain $X$, then the specific hypothesis is accepted by $d k=n-2$. In this calculation the $t$ count $=6,477$ whereas the $t$ table is 1,682 for significant level of 0.05 and $t=$ table 2,698 for significant levels of 0.01 , means that $\mathrm{t}$ count is bigger than $\mathrm{t}$ table then the hypothesis is accepted with $\mathrm{dk}=$ $44-2=42$ To see the influence of organizational communication on employee's performance, use the following formula:

$\mathrm{Y}=\mathrm{a}+\mathrm{bx}$

But to find out the value of the regression coefficient, the calculated formula is:

$$
\begin{gathered}
b=\frac{n\left(\sum x y\right)-\left(\sum x\right)\left(\sum y\right)}{n\left(\sum x^{2}\right)-\left(\sum x\right)^{2}} \\
=\frac{44(74,864)-(1782)(1806)}{44(74,562)-(1782)^{2}} \\
=\frac{(3,294,016)-(3,218,292)}{(3,280,728)-(3,175,524)} \\
=\frac{75,724}{105,204} \\
=0.71
\end{gathered}
$$


If $\mathrm{b}$ shows positive fuel of 0.09 , the influence of organizational communication towards performance of the employees is existed. To find out the value of $\mathrm{Y}$, a constant value (intercept) needs to be sought by using this following formula:

$$
\begin{gathered}
a=\frac{\left(\sum y\right)\left(\sum x^{2}\right)-\left(\sum x\right)\left(\sum x y\right)}{n\left(\sum x^{2}\right)-\left(\sum x\right)^{2}} \\
=\frac{(1806)(74,562)-(1782)(74,864)}{44(74,562)-(1782)^{2}} \\
=\frac{(134,658,972-133,407,648)}{(3,280,728-3,175,524)} \\
=\frac{1,251,324}{105,204} \\
=11.89
\end{gathered}
$$

Therefore, the application of the formula to determine the influence of organizational communication towards employees' performance is:

$$
\begin{aligned}
\mathrm{Y} & =\mathrm{a}+\mathrm{bx} \\
& =11.89+0.71
\end{aligned}
$$

From the above calculation, the results show positive signs on the coefficients of regression $(b=0.71)$ means there is an increase in the value of $\mathrm{X}$, then the performance of employees will also increase and the relationship between them is the medium, showed $r=0.49$. Change in employees' performance levels can be affected by changes in the level of organizational communications i.e. amounting to $\mathrm{kd}=24 \%$. The calculation of correlation, regression and the organizational communication should always be owned by every employee, because it will improve the performance of the employees.

Discussion: Organizational communication is the important thing that should be owned by an employee, it is one of the factors that can improve the performance of employees at Badan Pendidikan dan Pelatihan Kerja in Makassar City. The more frequent communication in an organization, the better the performance will be.

Based on the obtained hypothesis testing results, an influence among organizational communication variables to employees' performance in Badan Pendidikan dan Pelatihan in Makassar City was discovered, where t test and test result $t$ count $>t$ table was applied. This means that the hypothesis in this study stated an influence of organizational communication to the performance of employees at Badan Pendidikan dan Pelatihan in Makassar City is acceptable.

The contribution of the organizational communication towards performance variable can be seen from the value of the determinant of the coefficient obtained by $24 \%$. Thus, the influence of organizational communication towards employees' performance is $11.89 \%$. Others are influenced by various factors which are not examined in this research. It can be seen that if organizational communication of employees increases, positive employees' performance will certainly follow. The organizational communication affect the employees' performance and this situation can be seen from the result of linear regression calculation adjusted for 0.877 . Therefore, organizational communication factors must exist and needs to be sustained because good organization communication will improve the performance of employees. Organizational communication applied in organizations/institution is one of the efforts to improve the performance of employees.

\section{Conclusion and Recommendations}

Based on the explanation on the results of the research and the discussion, conclusions can be expressed as follows:

- Based on the research that has been done on the description of organizational communication in Badan Pendidikan dan Pelatihan in Makassar City, this institution is in good category and affects employees' performance. It can be seen from effective bottom communication, effective upward communication and effective horizontal communication. 
- Description of the level of performance in Badan Pendidikan dan Pelatihan in the Makassar City is satisfying, because the effect of organizational communication towards employees' performance was found, and this can be seen from the quality, quantity and timeliness.

- The effect of organizational communication in Badan Pendidikan dan Pelatihan in Makassar City is in the medium level based on the evident from the results of hypothesis testing.

The importance of communication in the organization is undisputable consequence. Organizational communication allows the company to obtain a valuable result which is unachievable by any standalone individuals. It is then understood that without cooperation from individuals in the organization, the organizational goal is not achievable. Within this context, communication is playing a very critical role to develop cooperation between individuals in the organization, and in such that it will increase the employee's performance. Good organizational communication may put the organization in the position to achieve the objective through activities which are planned, coordinated and evaluated by pursuing for good communication between employees and superiors. Good communication can produce better employee's performance. The objective of the research is to understand the effect of organizational communication on employee performance Leadership at Badan Pendidikan dan Pelatihan in Makassar City.

Recommendations: Based on the above conclusions, suggestions are recommended as follows:

- For Leader: It is expected to the Leader of Badan Pendidikan dan Pelatihan in Makassar City to be more active in organizational communication in order to build a good partnership to subordinates.

- For Employees: It is expected to all employees at Badan Pendidikan dan Pelatihan in Makassar city to be more active in organizational communication in carrying out his duties as well as to maintain the level of performance of employees' capabilities.

\section{References}

Anonymous, K. (2002). Indonesian dictionary. Second Edition. Jakarta: Balai Pustaka

Arikunto, S. (2003). Research procedures. Jakarta: Rineke Cipta.

Arni, M. (2008). Organizational Communication. Jakarta: Bumi Aksara.

Hasibuan, M. S. P. (2007). Human Resource Management. Jakarta: Bumi Aksara

Irham, F. (2010). Performance Management. Bandung: Alfabeta.

Marzuki. (2002). Research Methodology. Yogyakarta: BPFE-UII

Prabu, M. A. (2002). Human Resource Management for Company. Bandung: Remaja Rosdakarya.

Soegiyono. (2003). Administration Research Methods. Bandung: Tarsito

Soeprihanto, J. (2000). Performance Assessment and Employee Development. Yogyakarta: BPFE

Sulistiyani. (2003). Human Resource Management. Yogyakarta: Graha Ilmu.

Reseach Team of Development of Accountability System for Performance Government. (2000). Performance Measurement. Jakarta: BPKP. 